\title{
Acceleration of Growth Rate in Growth Hormone-Deficient Children Treated with Human Growth Hormone-Releasing Hormone
}

\author{
MICHAEL O. THORNER, ALAN D. ROGOL, ROBERT M. BLIZZARD, \\ GEORGEANNA JONES KLINGENSMITH, JENNIFER NAJJAR, REETA MISRA, IAN BURR, \\ GEORGE CHAO, PAUL MARTHA, JAY MCDONALD, SUZAN PEZZOLI, JEAN CHITWOOD, \\ RICHARD FURLANETTO, JEAN RIVER, WYLIE VALE, PATRICIA SMITH, AND CHARLES BROOK \\ Departments of Internal Medicine, Pediatrics, and Pharmacology, University of Virginia School of Medicine, \\ Charlottesville, Virginia [M.O.T., A.D.R., R.M.B., P.M., J.M., S.P., J.C.]; the Department of Pediatrics, \\ Children's Hospital, Denver, Colorado [G.J.K.]; Vanderbilt University, Nashville, Tennessee [J.N., R.M., I.B.]; \\ Tufts New England Medical Center, Boston, Massachusettes [G.C.]; Children's Hospital of Philadelphia, \\ Philadelphia, Pennsylvania [R.F.]; the Clayton Foundation Laboratories for Peptide Biology, Salk Institute, San \\ Diego, California [J.R., W.V.]; and the Endocrine Unit, The Middlesex Hospital, London,
} United Kingdom [P.S., C.B.]

\begin{abstract}
Twenty-four growth hormone-deficient children were treated with growth hormone releasing hormone40 (GHRH) for 6 months or longer. GHRH (1 to $4 \mu \mathrm{g} / \mathrm{kg}$ of body weight per dose) was administered subcutaneously every $3 \mathrm{~h}(n=10)$; or every 3 h overnight only $(n=10)$; or by twice daily injections $(n=4)$. Twenty-one children had an increase in growth rate during GHRH treatment. The growth velocities (mean $\pm \mathrm{SD} ; \mathrm{cm} / \mathrm{yr}$ ) before and during treatment were, respectively: every 3 h $3.5 \pm 1.4$ versus $10.0 \pm 2.2, p=0.0001$; overnight only $3.4 \pm 1.0$ versus $6.2 \pm 2.1, p=0.008$; twice daily injections $3.2 \pm$ 1.8 versus $7.9 \pm 2.4, p=0.06$. Using these three modes of GHRH administration, different total daily amounts of GHRH were administered. Regression analysis of average daily dose versus growth velocity revealed a correlation coefficient $(r)$ value of $0.57, p=0.004$. Sixteen children received extendet treatment for periods varying from 9 to 30 months. Of these, seven children were treated continuously for 9 months with pump overnight only and 5 for 12 months with pump every $3 \mathrm{~h}$. Their growth velocities were sustained at a similar rate as those observed at 6 months. Six children received both twice daily and three hourly treatments consecutively. The growth velocities were similar during both treatments. Eleven children developed circulating antibodies to GHRH during treatment, however, all 11 had accelerated growth rates during GHRH therapy. GHRH can stimulate growth hormone secretion and its biologic effects to accelerate linear growth in children with growth hormone deficiency. Further studies are required to characterize the optimal dose and frequency of administration. (Pediatr Res 24: 145-151, 1988)
\end{abstract}

\section{Abbreviations}

GHRH, growth hormone-releasing hormone GH, growth hormone

hGH, human growth hormone

Received December 22, 1987; accepted March 15, 1988.

Correspondence and reprint requests, Dr. Michael O. Thorner, Department of Internal Medicine, Box 511, University of Virginia School of Medicine, Charlottesville, VA 22908.

Supported in part by grants from the United States Public Health Service (General Clinical Research Centers) at University of Virginia RR00847; Children's Hospital, Denver RR00069; Vanderbilt University RR00095; Tufts New England Medical Center RR00054; and Grant AM32632 and a March of Dimes Birth Defects Foundation grant to M.O.T.; AG04303 to R.M.B. and AM26741, AM209177, AA03504, and HD13527 to the Clayton Foundation Laboratories.
The majority of GH-deficient children with short stature and growth failure have a disorder of hypothalamic regulation of the anterior pituitary rather than a defect of the somatotrope. In these children single injections of GHRH may stimulate $\mathrm{GH}$ secretion. We have previously reported preliminary results of GHRH therapy in seven GH-deficient children (1-3) and now report a multicenter trial of this therapy in 24 patients treated for 6 months or more.

\section{METHODS}

Twenty-four children with short stature, growth failure, and GH deficiency secondary to idiopathic or organic hypopituitarism were enrolled in the study after they assented and their parents gave written informed consent. The study was approved by the Human Investigation Committees of the University of Virginia, the Salk Institute, The Middlesex Hospital, the University of Colorado School of Medicine, Vanderbilt School of Medicine, and Tufts New England Medical Center, and by the United States Food and Drug Administration. Each child was admitted to the respective center before starting the study and underwent a physical examination with special emphasis on growth characteristics and assessment of his/her endocrine function, including standard test(s) of growth hormone reserve: levo-dopa, $7 \mathrm{mg} /$ $\mathrm{kg}$ of body weight, by mouth, and arginine, $0.5 \mathrm{~g} / \mathrm{kg}$ by intravenous infusion over a 30 -min period; and/or insulin-induced hypoglycemia, 0.075 to $0.1 \mathrm{U} / \mathrm{kg}$, intravenously; or clonidine, $0.15 \mathrm{mg} / \mathrm{m}^{2}$ and insulin, $0.1 \mathrm{U} / \mathrm{kg}$. In addition, radiologic examination included determination of bone age $(4,5)$ and high resolution CT scanning of the head. The criteria for admission into the protocol included observation of the child for at least 6 months to document that: 1 ) the growth velocity was less than 5 $\mathrm{cm} / \mathrm{yr}, 2$ ) the child was prepubertal, and 3) peak $\mathrm{GH}$ concentrations after pharmacologic test(s) were less than $10 \mathrm{ng} / \mathrm{ml}$. All children had a $\mathrm{GH}$ response to $\mathrm{GHRH}$ with a minimum peak of $3.2 \mathrm{ng} / \mathrm{ml}$ (range of 3.2-106.9 ng/ml). Three children had been previously treated with growth hormone (no. 2 for $1.2 \mathrm{yr}$, no. 7 for $0.5 \mathrm{yr}$, and no. 9 for $3.6 \mathrm{yr}$ ). $\mathrm{hGH}$ treatment was discontinued at least 6 months before entry into the study.

After the initial hospitalization each child was discharged home with a supply of human GHRH(1-40)-OH, synthesized in the Clayton Foundation Laboratories for Peptide Biology at the Salk Institute and formulated as previously described (1). GHRH was administered subcutaneously either twice daily by injection or by means of a Pulsamat pump (courtesy of Dr. Daniel Linkie, Ferring Laboratories, Inc., Ridgewood, NJ), which has a reservoir 
that contains peptide solution for at least 14 days of therapy. Ten children received GHRH by pump throughout the $24-\mathrm{h}$ period at $3-\mathrm{h}$ intervals at a dose of 1 to $3 \mu \mathrm{g} / \mathrm{kg} / \mathrm{pulse}$. An additional 10 children received GHRH by pump administered at 3-h intervals over $12 \mathrm{~h}$, overnight only, at a dose of 1 to $2 \mu \mathrm{g} /$ $\mathrm{kg} /$ pulse (The Middlesex Hospital). Four children received GHRH for 6 months by twice daily injections of $4 \mu \mathrm{g} / \mathrm{kg} /$ dose. Sixteen children have received extended treatment for periods varying from 9 to 30 months.

The children were seen at a minimum of 4-wk intervals at which time a blood sample was drawn for measurement of somatomedin $\mathrm{C}$ concentration and for the presence of antiGHRH antibody. In addition, height was measured every 4 wk upon arising in the morning by a single observer using a Harpenden stadiometer. Immediately before starting treatment and after 6 months of therapy each child underwent a test with GHRH, 1 $\mu \mathrm{g} / \mathrm{kg}$ as an intravenous bolus; this was performed at the same time of day on each occasion $3 \mathrm{~h}$ after the previous subcutaneous dose.

Serum growth hormone, somatomedin C, thyrotropin, and thyroxine concentrations were measured either by radioimmunoassay as previously described $(1,3)$ or by immunoradiometric assay $(\mathrm{GH})$ using reagents purchased from Nichols Institute (San Juan Capistrano, CA). The sensitivity of the latter GH assay is $0.5 \mathrm{ng} / \mathrm{ml}$ and the inter- and intraassay coefficients of variability at $4.5 \mathrm{ng} / \mathrm{ml}$ were 7.1 and $5.5 \%$. The sera collected to determine if antibodies to GHRH had developed were examined at final concentrations of 1:50,1:100,1:500, and 1:1000. Antibody bound $\left[{ }^{125} \mathrm{I}\right]-\mathrm{GHRH}(1-40)-\mathrm{OH}$ was separated from free tracer by goat anti-human $\gamma$-globulin (Scantibodies, lot no. R496F). As a control for the quality of the tracer, it was tested with rabbit antihuman GHRH(1-40)-OH (7Q) and bound $40 \%$ at 1:200,000. Antibodies to GHRH were considered to be present when GHRH binding was $>2$-fold nonspecific binding $(1,2)$.

Analysis. Absolute growth velocities after 6 months and 9 months of treatment and the incremental growth velocities (the change in growth from pretreatment to 6 or 9 months of treatment) were compared. An increment or change in growth velocity of $\geq 1.8 \mathrm{~cm} / \mathrm{yr}$ was arbitrarily considered a significant response to GHRH therapy inasmuch as it is outside the random measurement error for consecutive measurements over a 6-month period.

Analysis of variance was used to compare the results of three treatment regimens. The Student's $t$ test was used for all other analyses. A $p$ values of $\leq 0.05$ was considered significant. Linear regression analysis was used to identify the strength of the relationship between the average daily dose $(\mu \mathrm{g} / \mathrm{kg} /$ day $)$ and increase in growth rates.

Patients treated. Preliminary results of seven of these children were previously reported, but their extended treatment periods are included to give a more complete overview (1-3). Details of pretreatment evaluation of each child are shown in Appendix Tables 1-3 in appendix and are listed by initial therapy. The peak $\mathrm{GH}$ response to any of the two or more pharmacologic tests of GH reserve is shown. Twenty of the children had idiopathic GH deficiency and four had organic causes-idiopathic hydrocephalus, septo-optic dysplasia, posttraumatic, and subarachoid suprasellar cyst with hydrocephalus. One patient who entered the study is not included because of poor compliance with therapy.

All children fulfilled the criteria for growth retardation secondary to $\mathrm{GH}$ deficiency including short stature and subnormal growth velocity. The bone age was retarded when compared to the chronologic age, (mean $\pm \mathrm{SD}$ ) $6.1 \pm 2.6 \mathrm{yr}$ bone age versus $9.3 \pm 2.5 \mathrm{yr}$ chronologic age, $p<0.0001$. The peak growth hormone concentration after a pharmacologic test was $\leq 10 \mathrm{ng}$ / $\mathrm{ml}$. In every child tested the peak GH response to GHRH was greater than to the pharmalogic test $(\mathrm{s})$. The mean $( \pm \mathrm{SD} ; \mathrm{ng} / \mathrm{ml})$ after GHRH was $27.6 \pm 23.9$ versus $3.3 \pm 2.5$ after pharmacologic test, $p<0.0001, n=23$. Analysis of variance demonstrated no significant differences in the pretreatment measurements among the three treatment groups.

\section{RESULTS}

\section{GROWTH VELOCITY}

\section{Initial 6 Months.}

GHRH treatment administered by pump every $3 \mathrm{~h}$. Ten children were treated with GHRH by pump every $3 \mathrm{~h}$ for six months. A dose of $1 \mu \mathrm{g} / \mathrm{kg} /$ pulse was given to five children and increased to $3 \mu \mathrm{g} / \mathrm{kg} / \mathrm{pulse}$ in two. Five children were treated with a dose of $2 \mu \mathrm{g} / \mathrm{kg} /$ per pulse throughout (Fig. 1, left).

The growth velocity (mean $\pm \mathrm{SD} ; \mathrm{cm} / \mathrm{yr}$ ) before treatment was $3.5 \pm 1.4$ versus $10.0 \pm 2.2$ at the end of treatment, $p=$ 0.0001 . All children grew at an accelerated velocity ranging from 7.1 to $14.1 \mathrm{~cm} / \mathrm{yr}$ during treatment. The increase in growth velocity (mean $\pm \mathrm{SD}$ ) was $6.5 \pm 2.5 \mathrm{~cm} /$ year.

GHRH treatment administered by pump every $3 \mathrm{~h}$; overnight only. Five children were treated at a dose of $1 \mu \mathrm{g} / \mathrm{kg} /$ pulse for 12 wk after which the dose was doubled. An additional five children were treated throughout with $2 \mu \mathrm{g} / \mathrm{kg} /$ pulse (Fig. 1, middle).

The growth velocity (mean $\pm \mathrm{SD} ; \mathrm{cm} / \mathrm{yr}$ ) before treatment was $3.4 \pm 1.0$ versus $6.2 \pm 2.1$ at the end of treatment, $p=0.008$. Seven of the 10 patients grew at an accelerated velocity ranging from 5.0 to $8.9 \mathrm{~cm} / \mathrm{yr}$ during treatment, however, two subjects (nos. 13 and 15) had a decrease in their growth velocities (from 4.8 to 3.4 and from 4.2 to 3.8 , respectively). One subject (no. 16) showed an increase of only $1.4 \mathrm{~cm} / \mathrm{yr}$ (from 3.3 to $4.7 \mathrm{~cm} /$ yr).

GHRH treatment administered by twice daily injections. Four children were treated for six months with twice daily injections of GHRH, $4 \mu \mathrm{g} / \mathrm{kg} /$ dose (Fig. 1, right).

The pretreatment growth velocity (mean $\pm \mathrm{SD} ; \mathrm{cm} / \mathrm{yr}$ ) was $3.2 \pm 1.8$ versus $7.9 \pm 2.4$ during treatment, $p=0.06$. All four grew at an accelerated velocity ranging from 6.1 to $11.4 \mathrm{~cm} / \mathrm{yr}$ on therapy. The increase in growth velocity (mean $\pm \mathrm{SD}$ ) was $4.8 \pm 3.2 \mathrm{~cm} / \mathrm{yr}$.

Comparison of absolute and incremental growth velocities (mean $\pm S D ; \mathrm{cm} / \mathrm{yr}$ ) of three different regimens over 6 months. The three treatment groups were comparable in terms of pretreatment chronologic age, bone age, peak $\mathrm{GH}$ response to pharmacologic test(s) and to GHRH (Appendix Tables 1-3).

The absolute growth velocity and the incremental growth velocity were greatest for GHRH administered every $3 \mathrm{~h}$, when compared with GHRH administered every $3 \mathrm{~h}$ overnight only. The mean $( \pm \mathrm{SD}$ ) absolute growth velocity (pump every $3 \mathrm{~h}$ versus pump overnight) was $10.0 \pm 2.2$ versus $6.2 \pm 2.1$ and the mean $( \pm \mathrm{SD})$ incremental growth velocity was $6.5 \pm 2.5$ versus $2.8 \pm 2.6$. In both cases, the mean velocities were significantly different ( $p<0.05$, Duncan's multiple comparison test).

GHRH administered by twice daily injections resulted in an intermediate increase which was not significantly different compared with either pump regimen. The means were $7.9 \pm 2.4$ for absolute growth velocity and $4.8 \pm 3.2$ for incremental growth velocity.

Dose of $G H R H$. The three GHRH regimens resulted in administration of different total daily amounts of GHRH. The use of the pump every $3 \mathrm{~h}$ resulted in administration of an average dose of 8,16 , or $19 \mu \mathrm{g} / \mathrm{kg} /$ day $(1,2$, or $3 \mu \mathrm{g} / \mathrm{kg} / \mathrm{dose})$. The overnight treatment by pump resulted in administration of an average dose of 6 to $8 \mu \mathrm{g} / \mathrm{kg} /$ day. The twice daily regimen resulted in a dose of $8 \mu \mathrm{g} / \mathrm{kg} / \mathrm{day}$. Regression analysis of average daily dose (irrespective of regimen) versus growth velocity revealed a correlation coefficient $(r)$ value of $0.57, p=0.004$; growth velocity $(\mathrm{cm} / \mathrm{yr})=4.559+0.0346 \times$ average dose, $\mu \mathrm{g} /$ $\mathrm{kg} /$ day. For the relationship between dose and change in growth velocity the correlation coefficient $(r)$ value was $0.513, p=0.01$; 

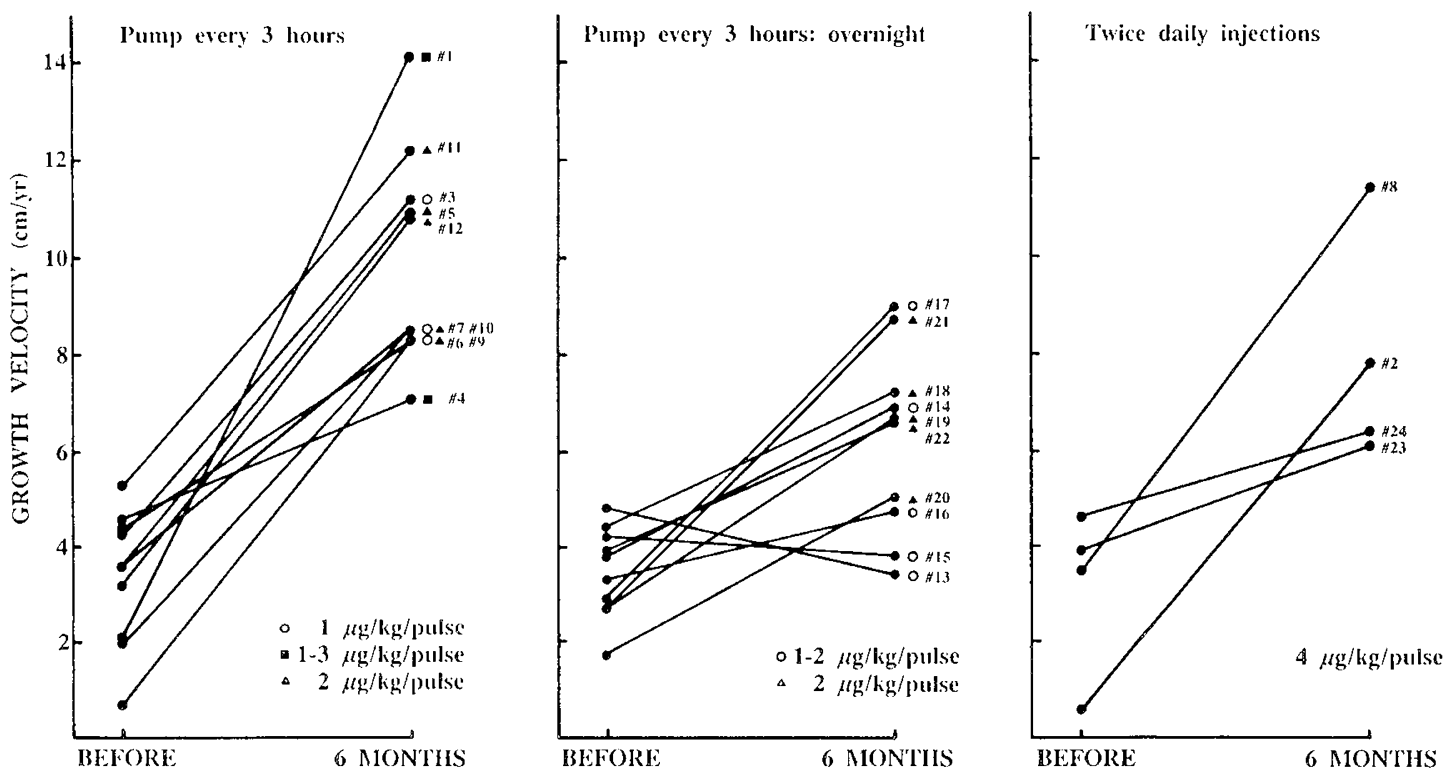

Fig. 1. The effect of three different regimens of GHRH therapy on growth velocity $(\mathrm{cm} / \mathrm{yr})$. Numbers refer to patients represented in Appendix Tables 1-3.

growth velocity $(\mathrm{cm} / \mathrm{yr})=1.100+0.351 \times$ average dose, $\mu \mathrm{g} / \mathrm{kg} /$ day.

Longer Term Treatment.

GHRH treatment administered by pump every $3 \mathrm{~h}$. Five children were treated continuously for 12 months or more. Their growth velocities before, at 6,9 , and 12 months are shown individually in Figure 2. All children had an accelerated growth rate. One child (no. 5) had treatment extended to 18 months. Her growth velocities before, at $6,9,12$, and 18 months were $3.5,10.9,9.6,9.0$, and $9.1 \mathrm{~cm} / \mathrm{yr}$. At 12 months she was prepubertal and by 18 months she had Tanner stage II breast development $(6,7)$.

The mean growth velocities of these five children (mean $\pm \mathrm{SD}$; $\mathrm{cm} / \mathrm{yr}$ ) before, at 6,9 , and 12 months were $3.6 \pm 1.7,10.7 \pm$ $1.4,9.4 \pm 1.4$, and $8.6 \pm 1.2$, respectively, and were all significantly different from the pretreatment growth velocities and from each other, $p<0.002$.

GHRH treatment administered every $3 \mathrm{~h}$; overnight only. Treatment was extended to 9 months in seven of 10 children. Their growth velocities before, at 6 and 9 months are shown individually in Figure 3 . The mean growth (mean $\pm \mathrm{SD} ; \mathrm{cm} / \mathrm{yr}$ ) before and at 6 and 9 months were $3.4 \pm 0.7,6.8 \pm 2.2$, and 6.5 \pm 1.5 , respectively.

Comparison of absolute and incremental growth velocities (mean $\pm S D ; \mathrm{cm} / \mathrm{yr}$ ) of two different regimens over 9 months. The absolute growth velocity and the incremental growth velocity were greatest with GHRH administered every $3 \mathrm{~h}$, when compared with GHRH administered every $3 \mathrm{~h}$ overnight only. The mean ( $\pm \mathrm{SD}$ ) absolute growth velocity (pump every $3 \mathrm{~h}$ versus pump overnight) was $9.4 \pm 1.4$ versus $6.5 \pm 1.5$ and the mean $( \pm \mathrm{SD})$ for incremental growth velocity was $5.8 \pm 0.4$ versus 3.0 \pm 2.0 . In both cases, the mean velocities were significantly different $(p<0.01$, Student's $t$ test).

GHRH treatment administered by both pump and twice daily treatments in the same child. Six children received sequential GHRH therapy administered by pump and twice daily injections. Two of these children are included in the five who were treated continuously for 12 months with GHRH by pump every $3 \mathrm{~h}$. The treatments and the growth velocities are summarized in Table 1. All regimens were effective. The small number of subjects, the variable dose, and order of the therapies does not allow for precise conclusions to be drawn about optimal regimen.

Other Studies.

Peak GH response to intravenous bolus of GHRH. Twelve

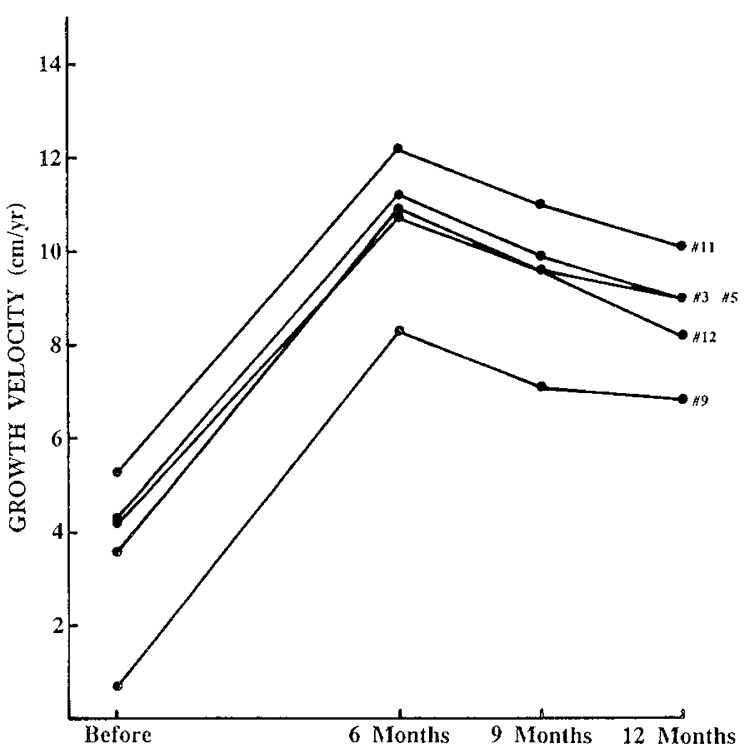

Fig. 2. The effect of 12 months of GHRH therapy administered by pump every $3 \mathrm{~h}$ on growth velocity $(\mathrm{cm} / \mathrm{yr})$.

patients had a greater response to the GHRH intravenous bolus injection at the end of the first 6 months of treatment compared with the pretreatment response. The response in nine patients was the same or was lower. The mean response for the group did not differ from pretherapy to that after 6 months of treatment.

Somatomedin $C$ and alkaline phosphatase concentrations. The somatomedin $\mathrm{C}$ concentrations for the 17 patients in whom both baseline and 6 months samples were available are summarized in Table 2. The pretreatment values did not differ among therapeutic groups. Similarly, the maximal somatomedin $C$ concentrations measured during therapy and after 6 months of therapy did not differ significantly among groups. The mean $( \pm$ SD) somatomedin $\mathrm{C}$ concentration increased from a pretreatment value of $0.22 \pm 0.24$ to $0.30 \pm 0.27 \mathrm{U} / \mathrm{ml}$ after 6 months, $p<$ 0.05 . Wide fluctuations in somatomedin $\mathrm{C}$ levels were observed during treatment and the mean maximal somatomedin $\mathrm{C}$ concentration for the group $(0.40 \pm 0.30 \mathrm{U} / \mathrm{ml})$ was significantly increased from the pretreatment value, $p<0.01$. The alkaline 
phosphatase concentrations did not vary with treatment (data not shown).

Antibody development. Eleven children developed circulating antibodies to GHRH at $\leq 1: 500$ dilution during therapy. However, all 11 had accelerated growth rates during GHRH therapy. Nine children treated with GHRH by pump developed low titer antibodies to GHRH, although in one (no. 7) the antibody concentration was detected only after the change to twice daily injections. One of four subjects treated initially with twice daily injections developed antibodies. Antibody titers were below the level of detectability (1:50) in 10 of the 11 children either during continuation of treatment (three patients) or after stopping treatment.

\section{DISCUSSION}

Once GHRH was isolated, characterized, and synthesized in 1982 , its role as a therapeutic agent for treatment of GH deficiency needed to be established. Our preliminary studies of GHRH therapy in which two and five children, respectively, had an acceleration of growth velocity during intermittent pulsatile

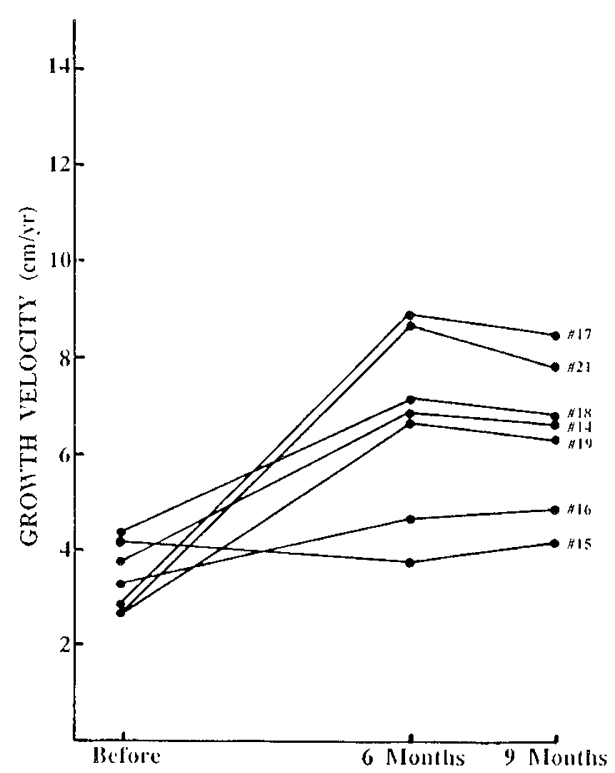

Fig. 3. The effect of nine months of GHRH therapy administered by pump every $3 \mathrm{~h}$, overnight only, on growth velocity $(\mathrm{cm} / \mathrm{yr})$.
GHRH treatment suggested that this peptide is effective therapy $(1-3)$. Similarly, other investigators reported that administration of GHRH by once or twice daily injections or by pump resulted in acceleration of growth velocity $(8-10)$. This study was designed to evaluate efficacy of GHRH therapy in a larger number of patients during three different treatment regimens that used a variety of doses. These results are pooled data from a collaborative study at five hospitals and demonstrate that GHRH therapy was effective in promoting acceleration of growth velocity in 21 of $24 \mathrm{GH}$-deficient children $(88 \%)$. The three children who did not respond received GHRH administered by pump overnight only (with the lowest average dose of 6 or $8 \mu \mathrm{g} / \mathrm{kg} /$ day) and who therefore received only half of the dose compared with children treated by pump throughout the 24-h period.

Acceleration of growth velocity was achieved by administering GHRH either by pump every $3 \mathrm{~h}$ over a 24 -h period, every $3 \mathrm{~h}$ overnight only or by twice daily injections. The best results occurred when GHRH was given every 3 h by pump over a 24 h period; these children also received a larger daily dose than did the others. The average (mean $\pm \mathrm{SD} ; \mu \mathrm{g} / \mathrm{kg} /$ day) doses administered during the three regimens were $14.2 \pm 4.4$ (pump over a 24-h period), $7.0 \pm 1.1$ (pump overnight only), and 8.0 (twice daily injections). Inasmuch as the same doses were not administered during each treatment regimen, it is not possible to determine if GHRH administration every $3 \mathrm{~h}$ by pump is more efficacious than the other regimens. However, results of the regression analysis that correlate average daily dose with growth velocity suggest that the total daily dose is of critical importance.

We initially proposed that stimulation of the somatotrope every $3 \mathrm{~h}$ with GHRH would mimic the normal GH secretory pattern and thus promote growth (1). Evidence supporting this hypothesis came from the studies by Clark et al. (11) who reported that rats given $\mathrm{GH}$ by continuous infusion did not grow as well as when the same dose was given intravenously every 3

h. However, observations that administration of pharmacologic

Table 2. Somatomedin $C(U / m l$, mean $\pm S D)$ by therapy group

\begin{tabular}{lcccc}
\hline \multicolumn{1}{c}{ Therapy } & $n$ & Pretreatment & $6 \mathrm{Mo}$ & \multicolumn{1}{c}{ Maximal } \\
\hline Pump every $3 \mathrm{~h}$ & 9 & $0.24 \pm 0.28$ & $0.33 \pm 0.23$ & $0.46 \pm 0.26^{*}$ \\
Overnight & 8 & $0.22 \pm 0.28$ & $0.33 \pm 0.40$ & $0.41 \pm 0.41$ \\
Twice daily & 3 & $0.18 \pm 0.12$ & $0.17 \pm 0.12$ & $0.19 \pm 0.12$ \\
& & & & \\
All groups & 17 & $0.22 \pm 0.24$ & $0.30 \pm 0.27 \dagger$ & $0.40 \pm 0.30^{*}$ \\
\hline
\end{tabular}

*Versus pretreatment $p<0.01$.

$\uparrow$ Versus pretreatment $p<0.05$.

Table 1. Comparison of growth velocities $(\mathrm{cm} / \mathrm{yr})$ in patients treated with more than one regimen

\begin{tabular}{|c|c|c|c|c|c|c|c|c|c|c|c|c|c|c|c|c|}
\hline \multirow[b]{3}{*}{ Patient } & \multirow[b]{3}{*}{ Pretreatment } & \multicolumn{5}{|c|}{ Therapy 1} & \multicolumn{5}{|c|}{ Therapy 2} & \multicolumn{5}{|c|}{ Therapy 3} \\
\hline & & \multirow{2}{*}{\multicolumn{2}{|c|}{$\begin{array}{c}\text { Daily } \\
\text { dose } \\
(\mu \mathrm{g} / \mathrm{kg} / \\
\text { day })\end{array}$}} & \multicolumn{3}{|c|}{ Mo of therapy } & \multirow{2}{*}{\multicolumn{2}{|c|}{$\begin{array}{l}\text { Daily } \\
\text { dose } \\
(\mu \mathrm{g} / \mathrm{kg} / \\
\text { day })\end{array}$}} & \multicolumn{3}{|c|}{ Mo of therapy } & \multirow{2}{*}{\multicolumn{2}{|c|}{$\begin{array}{c}\text { Daily } \\
\text { dose } \\
(\mu \mathrm{g} / \mathrm{kg} / \\
\text { day })\end{array}$}} & \multicolumn{3}{|c|}{ Mo of therapy } \\
\hline & & & & 6 & 9 & 12 & & & 6 & 9 & 12 & & & 6 & 9 & 12 \\
\hline 6 & 4.4 & $\mathrm{P}^{*}$ & 8 & 8.3 & & & $\mathrm{~B} \dagger$ & 8 & $10.2 \ddagger$ & 11.1 & 11.8 & $\mathrm{~B}$ & 8 & 10.9 & 10.6 & 10.2 \\
\hline 7 & $2.0 \S$ & $\mathrm{P}$ & 8 & 8.5 & & & $\mathrm{~B}$ & 8 & $7.7^{\circ}$ & 6.2 & 5.9 & & & & & \\
\hline 11 & $5.3^{\circ}$ & $\mathrm{P}$ & 16 & 12.2 & 11.0 & 10.1 & $\mathrm{~B}$ & 8 & 9.2 & 9.8 & 8.7 & & & & & \\
\hline 12 & 4.2 & $\mathrm{P}$ & 16 & 10.8 & 9.6 & 8.2 & $\mathrm{~B}$ & 8 & 7.4 & 7.0 & 6.9 & & & & & \\
\hline 8 & 3.5 & B & 6 & 11.4 & & & $\mathrm{P}$ & 16 & 7.8 & & & & & & & \\
\hline 2 & $0.6^{*}$ & B & 8 & 7.8 & & & $\mathrm{P}$ & 8 & 5.1 & & & $\mathrm{~B}$ & 8 & 6.0 & 6.3 & 5.8 \\
\hline
\end{tabular}

* Pump every $3 \mathrm{~h}$.

$\uparrow$ b.i.d. injections.

$\mp$ Begun pubertal development, with increase over 5 months of treatment in testicular size from 3 to $5 \mathrm{ml}$ and serum testosterone 67 to $96 \mathrm{ng} / \mathrm{dl}$, respectively.

$\S$ Off GH for 6 months. Growth velocities on National Pituitary Growth Hormone ( $2 \mathrm{U}$ three times/wk), no. 7 (for six months) was $9.6 \mathrm{~cm} / \mathrm{yr}$, no. 2 (for 18 months) was $7.8 \mathrm{~cm} / \mathrm{yr}$.

|| Questionable compliance taking thyroid medication during last 6 months. 
doses of hGH to GH-deficient children three times weekly promotes growth acceleration suggest that the frequency of administration may not be the most important factor. Whether GHRH is equivalent, inferior, or superior to hGH treatment of $\mathrm{GH}$ deficient children is an important practical question that was not addressed in this study. The goal of this study was to determine if a large number of $\mathrm{GH}$-deficient children would respond to GHRH and, if possible, to determine the optimal dose and frequency of administration. The maximal growth rate occurred after 6 months of therapy when GHRH was administered by pump over a $24-\mathrm{h}$ period. The growth velocity declined slightly over the next 6 months. These observations are similar to the pattern of growth observed in GH-deficient children treated with pituitary-derived and recombinant hGH $(12,13)$. It should be noted that the mean $( \pm S D)$ increase in growth velocity during the first 12 months of hGH therapy was $10.5 \pm 2.2 \mathrm{~cm} / \mathrm{yr}(13)$ when a dose of $0.1 \mathrm{mg} / \mathrm{kg}$ of methionyl-hGH or pituitary hGH (Kabi Vitrum AB, Stockholm, Sweden) was given three times a week. This is a larger dose than that used in earlier studies of pituitary-derived hGH. The growth velocity achieved during hGH therapy is similar to the mean $( \pm \mathrm{SD})$ growth velocity achieved during the first 6 months of GHRH administration by pump every $3 \mathrm{~h}$ of $10.0 \pm 2.2 \mathrm{~cm} / \mathrm{yr}$ (range of $7.1-14.1 \mathrm{~cm} / \mathrm{yr}$ ). In children treated with GHRH for more than 6 months, accelerated growth was sustained for 1 yr or longer. Inasmuch as the majority of patients had a good response to GHRH treatment, it is now feasible to perform a controlled study to compare the effects of GHRH and hGH therapy. It appears that GHRH is effective when given once daily (8). Therefore, the continued use of pump administration may now be an academic rather than practical consideration. In our study where patients and their parents were carefully selected, use of the pump did not present a major problem.

The GH response to an intravenous dose of GHRH did not increase after 6 months of treatment and this is not altogether surprising for several reasons. The response to GHRH is variable in normal subjects and GH-deficient patients. Additionally, variable response to GHRH occurs when the same subject is given a dose on different days. All patients had a brisk $\mathrm{GH}$ response to GHRH before the initiation of therapy which suggests that the somatotrope did not require "priming." Furthermore, the intravenous dose used was a maximal dose, and a change in sensitivity to GHRH would likely not be detectable.

A modest increase in serum somatomedin $\mathrm{C}$ concentrations was observed after 6 months of GHRH therapy. This was somewhat surprising inasmuch as a large increase was observed during short-term GHRH therapy and in the two previously reported patients $(1,14)$. The reason for this difference is not known. Wide fluctuations in serum somatomedin $C$ levels were observed during therapy and the mean maximal level was significantly increased compared with the mean pretreatment level. This lack of correlation between somatomedin $\mathrm{C}$ levels and growth rate has also been observed in children treated with hGH (15). These findings support the hypothesis that somatomedin $\mathrm{C}$ has an autocrine or paracrine function and that local somatomedin production by peripheral tissues, e.g. epiphyseal plate, and not the circulating homone concentration, is most important for stimulating linear growth.

Antibodies to GHRH developed in 11 of 24 patients. The clinical significance of these antibodies is unknown because growth acceleration and the $\mathrm{GH}$ response to intravenous GHRH were maintained. The antibody titers decreased in all children either during continued GHRH therapy or after discontinuation of treatment. Other investigators have reported development of anti-GHRH antibodies that were not associated with failure to respond to therapy $(8,9)$.

Our results are in agreement with those of Low et al. (10) who treated seven GH-deficient children with GHRH by pump for 12 months and with the only other 1-yr study published in which GHRH was administered once daily $(10 \mu \mathrm{g} / \mathrm{kg} /$ day $)(8)$. How- ever, our results differ in several important respects from the only other large published series (9). Ross et al. (9) selected a different population of GH-deficient children, most of whom had been treated with hGH within the preceding 3 to 6 months. Only three of the 24 patients in our study had received hGH that was discontinued for at least 6 months before GHRH treatment. An equipotent GHRH analog was used and the dose range was higher, $25-50 \mu \mathrm{g} / \mathrm{kg} /$ day. The maximum dose in our study was $19 \mu \mathrm{g} / \mathrm{kg} /$ day. Despite the larger GHRH doses used by Ross et al. (9), only eight of 18 patients had accelerated growth after 6 months of treatment. During prior hGH therapy, the "nonresponders" had lower growth rates than did the "responders." There was little, if any, "catch down growth" after withdrawal of hGH therapy which suggests that these nonresponders may have had incomplete GH deficiency. The dose of GHRH is unlikely to account for the lower incidence of accelerated growth in the study by Ross et al. (9) because they used a higher dose than was used in our study. However, there is no information on bioavailability of the GHRH analog which may also influence efficacy.

Some major questions remain, including whether optimal growth is maintained during stimulation of pulsatile GH secretion. If this concept is correct, then repeated administration of GHRH or use of a sustained-release GHRH preparation is a feasible method of therapy to maintain pulsatile GH secretion. To date, there appears to be minimal toxicity with the exception of development of antibodies to GHRH, which appears to be of little practical importance. The cost of hGH or GHRH depends on manufacturing and development costs and on market forces. If GHRH is to succeed as an alternative to $\mathrm{hGH}$, it must be at least as efficacious, be more convenient to administer, and less costly than hGH.

In summary, this multicenter study demonstrates that GHRH therapy is effective in accelerating growth in GH-deficient children. The results suggest that a dose of at least $8 \mu \mathrm{g} / \mathrm{kg} /$ day $(i . e$. $1 \mu \mathrm{g} / \mathrm{kg} / \mathrm{dose}$ every $3 \mathrm{~h}$ or $4 \mu \mathrm{g} / \mathrm{kg}$ b.i.d.) is required. Additionally, administration of $1 \mu \mathrm{g} / \mathrm{kg} /$ dose every $3 \mathrm{~h}$ overnight only did not promote the same growth response as when GHRH was administered every $3 \mathrm{~h}$ throughout the 24 -h period. The optimal mode of therapy, whether pulsatile or by once or twice daily subcutaneous injections, needs to be determined and a dose-response study with a fixed regimen is necessary. There are theoretical reasons and preliminary data to suggest that a sustained release GHRH preparation may be effective in restoring pulsatile $\mathrm{GH}$ secretion and consequent growth acceleration in GH-deficient children (16).

Acknowledgments. The authors are indebted to the staff of the Clinical Research Centers where these studies were performed for their expert nursing and technical assistance; to Drs. Seymour Reichlin and Boris Senior for their collaboration; to Ms. Donna Harris for helping to prepare the manuscript; to Mss. Pattie Hellmann, Fotini Beziriannidis, Ginger Bauler, and Catherine Cassada and Mr. Anthony Amos for technical assistance; to Dr. Mary Lee Vance for editorial assistance; and to Dr. Donald Kaiser and Mr. David Boyd for data management and statistical analysis using CLINJFO at the University of Virginia, Clinical Research Center. We thank Serono Laboratories, Inc. (Boston, MA) for providing indemnification for some of these studies.

\section{REFERENCES}

1. Thorner MO, Reschke J, Chitwood J, Rogol AD, Furlanetto R, Rivier J, Vale W, Blizzard RM 1985 Acceleration of growth in two children treated with human growth hormone releasing factor. N Engl J Med 312:4-9

2. Thorner MO, Reschke J, Chitwood J, Rogol AD, Furlanetto R, Rivier J, Vale W, Blizzard RM 1985 Development of antibody to growth hormone releasing factor. N Engl J Med 312:994

3. Smith PJ, Brook CGD, Rivier J, Vale W, Thorner MO 1986 Nocturnal pulsatile growth hormone releasing hormone treatment in growth hormone deficiency. Clin Endocrinol 25:35-44

4. Greulich WW, Pyle SI 1959 Radiographic Atlas of Skeletal Development of the Hand and Wrist, 2nd ed. Stanford University Press, Stanford, CA. 
5. Tanner JM, Whitehouse RH, Marshall WA, Healy MJR, Goldstein H 1975 Assessment of Skeletal Maturity and Prediction of Adult Height (TW 2 Method). Academic Press, Inc., New York

6. Tanner JM, Whitehouse RH, Takaishi M 1966 Standards from birth to maturity for height, weight, height velocity, and weight velocity: British children, 1965. Part I. Arch Dis Child 1966; 41:454-471.

7. Tanner JM, Whitehouse RH, Takaishi M 1966 Standards from birth to maturity for height, weight, height velocity, and weight velocity: British children, 1965. Part II. Arch Dis Child 41:613-635

8. Rochiccioli PE, Tauber M-T, Coude F-X, Arnone M, Morre M, Uboldi F, Barbeau C 1987 Results of 1-year growth hormone (GH)-releasing hormone(1-44) treatment on growth, somatomedin-C, and 24-hour GH secretion in six children with partial GH deficiency. J Clin Endocrinol Metab 65:268274

9. Ross RJM, Rodda C, Tsagarakis S, Davies PSW, Grossman A, Rees LH, Preece MA, Savage MO, Besser GM 1987 Treatment of growth-hormone deficiency with growth-hormone-releasing hormone. Lancet 1:5-8

10. Low LCK, Wang C, Cheung PT, Ho P, Lam KSL, Young RTT, Yeung CY, Ling $N 1988$ Long term pulsatile growth hormone $(\mathrm{GH})$-releasing hormone therapy in children with GH deficiency. J Clin Endocrinol Metab 66:611617
11. Clark RG, Jansson J-O, Isaksson O, Robinson ICAF 1985 Intravenous growth hormone: growth responses to patterned infusions in hypophysectomized rats. J Endocrinol 104:53-61

12. Frasier SD 1983 Human pituitary growth hormone (hGH) therapy in growth hormone deficiency. Endocrinol Rev 4:155-170

13. Kaplan SL, Underwood LE, August GP, Bell JJ, Blethen SL, Blizzard RM, Brown DR, Foley TP, Hintz RL, Hopwood NJ, Johansen A, Kirkland RT, Plotnick LP, Rosenfeld RG, Van Wyk JJ 1986 Clinical studies with recombinant-DNA-derived methionyl human growth hormone in growth hormone deficient children. Lancet 1:697-700

14. Borges JLC, Blizzard RM, Evans WS, Furlanetto R, Rogol AD, Kaiser DL, Rivier J, Vale W, Thorner MO 1984 Stimulation of growth hormone (GH) and somatomedin $\mathrm{C}$ in idiopathic $\mathrm{GH}$-deficient subjects by intermittent pulsatile administration of synthetic human pancreatic tumor GH-releasing factor. J Clin Endocrinol Metab 59:1-6

15. Rosenfeld RG, Kemp SF, Hintz RL 1981 Constancy of somatomedin response to growth hormone treatment of hypopituitary dwarfism, and lack of correlation with growth rate. J Clin Endocrinol Metab 53:611-617

16. Vance ML, Evans WS, Thorner MO 1986 Growth hormone secretion is augmented during 14 days of continuous growth hormone releasing hormone infusion in normal man. Clin Res 34:435A

APPENDIX TABLE 1

Pretreatment characteristics of patients treated with GHRH by pump every $3 \mathrm{~h}$

\begin{tabular}{|c|c|c|c|c|c|c|c|c|}
\hline Patient & $\begin{array}{c}\text { Chronologic age } \\
\text { (yr) }\end{array}$ & $\begin{array}{c}\text { Bone age } \\
(\mathrm{yr})\end{array}$ & $\begin{array}{c}\text { Peak GH } \\
\text { pharmacologic }\end{array}$ & $\begin{array}{c}\text { GHRH test } \\
(\mathrm{ng} / \mathrm{ml})\end{array}$ & $\begin{array}{l}\text { Growth velocity } \\
(\mathrm{cm} / \mathrm{yr})\end{array}$ & $\begin{array}{c}\text { Height } \\
(\text { SDS at CA)* }\end{array}$ & $\begin{array}{l}\text { Growth velocity } \\
\text { (SDS at CA)* }\end{array}$ & $\begin{array}{c}\text { Other hormonal } \\
\text { replacement } \dagger\end{array}$ \\
\hline \multicolumn{9}{|c|}{ University of Virginia } \\
\hline $1 \ddagger$ & 8.3 & 6 & $5.5 \S$ & 39 & 2.1 & -3.7 & -4.3 & \\
\hline 3 & 8.5 & 4.5 & $2.0 \|$ & 11.8 & 4.3 & -3.3 & -1.4 & \\
\hline 4 & 9.8 & 4.5 & $1.2 \S$ & 21 & 4.6 & -4.4 & -0.8 & $\mathrm{~F}, \mathrm{~T}_{4}$ \\
\hline 5 & 10.3 & 7.9 & $1.1 \|$ & 9.3 & 3.6 & -3.7 & -2.2 & \\
\hline \multicolumn{9}{|l|}{ Denver } \\
\hline 6 & 14.2 & 9.5 & $3.3 \pi$ & 45 & 4.4 & -3.1 & -3.9 & \\
\hline 7 & 9.9 & 7 & $1.7^{* *}$ & $>16$ & 2.0 & -2.7 & -4.5 & \\
\hline $9 \ddagger$ & 8.2 & 5 & 2.7 & 20.0 & 0.7 & -3.5 & -6.1 & \\
\hline \multicolumn{9}{|l|}{ Vanderbilt } \\
\hline 10 & 10 & 8 & $8.0 \|$ & 16.7 & 3.6 & -2.8 & -2.1 & \multirow{5}{*}{$\mathrm{T}_{4}$} \\
\hline 11 & 11 & 6 & $4.0^{* *}$ & 30.4 & $5.3+t$ & -2.3 & +0.4 & \\
\hline $12 \ddagger$ & 7.3 & 3 & $1.4 \|$ & 37.5 & 4.2 & -4.6 & -1.8 & \\
\hline Mean & 9.7 & 6.1 & 3.1 & 24.7 & 3.5 & & & \\
\hline$\pm \mathrm{SD}$ & 1.7 & 2.0 & 2.2 & 12.4 & 1.4 & & & \\
\hline Range & $\begin{array}{r}p=0 . \\
7.3-14.2\end{array}$ & $\begin{array}{l}101 \\
3.0-9.5\end{array}$ & $\begin{array}{r}p= \\
1.1-8.0\end{array}$ & $9.3-45$ & $0.7-5.3$ & $-2.3--4.6$ & $+0.4--6.1$ & \\
\hline
\end{tabular}

* SD score at chronologic age derived from tables of Tanner et al. (6)

$\uparrow \mathrm{F}$, hydrocortisone; $\mathrm{T}_{4}$, L-thyroxine.

+ Organic GH deficiency.

$\S \mathrm{L}$-dopa/arginine.

IInsulin tolerance test.

I L-dopa.

** Arginine.

$\dagger \dagger$ Original velocity provided by center was $4.2 \mathrm{~cm} / \mathrm{yr}$. 
APPENDIX TABLE 2

Pretreatment characteristics of patients treated with GHRH by pump overnight

\begin{tabular}{|c|c|c|c|c|c|c|c|c|}
\hline Patient & $\begin{array}{c}\text { Chronologic age } \\
\text { (yr) }\end{array}$ & $\begin{array}{c}\text { Bone age } \\
(\mathrm{yr})\end{array}$ & $\begin{array}{c}\text { Peak GH } \\
\text { Pharmacologic } \\
(\mathrm{ng} / \mathrm{ml})\end{array}$ & $\begin{array}{l}\text { GHRH test } \\
(\mathrm{ng} / \mathrm{ml})\end{array}$ & $\begin{array}{c}\text { Growth velocity } \\
(\mathrm{cm} / \mathrm{yr})\end{array}$ & $\begin{array}{c}\text { Height } \\
(\mathrm{SDS} \text { at CA })^{*}\end{array}$ & $\begin{array}{l}\text { Growth velocity } \\
\text { (SDS at CA)** }\end{array}$ & $\begin{array}{l}\text { Other hormonal } \\
\text { replacement } \dagger\end{array}$ \\
\hline \multicolumn{9}{|c|}{ Middlesex/London } \\
\hline 13 & 6.7 & 5.5 & $4.3 \dagger$ & 17.0 & 4.8 & -3.2 & -1.2 & \multirow{3}{*}{$\mathrm{T}_{4}$} \\
\hline 14 & 8.5 & 4.8 & $0.7 \ddagger$ & 12.8 & 3.8 & -2.5 & -2.2 & \\
\hline 15 & 8.3 & 6.6 & $9.9 \ddagger$ & 55.8 & 4.2 & -3.0 & -1.6 & \\
\hline 16 & 9.5 & 6.5 & $4.7 \ddagger$ & 26.6 & 3.3 & -2.1 & -2.7 & $\mathrm{~F}, \mathrm{~T}_{4}$ \\
\hline 17 & 11.8 & 7.7 & $1.9 \neq$ & 13.0 & 2.9 & -4.0 & -2.8 & \multirow[t]{2}{*}{$\mathrm{T}_{4}$} \\
\hline 18 & 5.0 & 2.4 & $6.4 t$ & 106.9 & 4.4 & -2.7 & -2.0 & \\
\hline 19 & 10.9 & 5.8 & $3.0 \ddagger$ & 61.3 & 2.7 & -0.7 & -3.4 & DDAVP \\
\hline 20 & 9.9 & 5.9 & $2.0 \ddagger$ & 5.7 & 1.7 & -3.8 & -4.6 & $\mathrm{~F}$ \\
\hline 21 & 6.5 & 2.0 & $1.8+$ & 13.3 & 2.7 & -3.0 & -3.5 & \multirow[t]{2}{*}{$\mathrm{F}, \mathrm{T}_{4}$} \\
\hline 22 & 9.8 & 8.8 & $6.8 \div$ & 59.9 & 3.9 & -2.2 & -1.8 & \\
\hline Mean & 8.7 & 5.6 & 4.2 & 37.2 & 3.4 & & & \\
\hline$\pm \mathrm{SD}$ & 2.1 & 2.1 & 2.9 & 32.6 & 1.0 & & & \\
\hline Range & $5.0-11.8$ & $2.0-8.8$ & $0.7-9.9$ & $5.7-106.9$ & $1.7-4.8$ & $-0.7--4.0$ & $-1.2--4.6$ & \\
\hline
\end{tabular}

* SD score at chronologic age derived from tables of Tanner et al. (6).

$\uparrow \mathrm{F}$, hydrocortisone; $\mathrm{T}_{4}$, L-thyroxine; DDAVP, desmopressin.

$\$$ Insulin tolerance test.

TABLE 3

Pretreatment characteristics of patients treated with GHRH by twice daily subcutaneous injections

\begin{tabular}{|c|c|c|c|c|c|c|c|c|}
\hline Patient & $\begin{array}{c}\text { Chronologic age } \\
\text { (yr) }\end{array}$ & $\begin{array}{c}\text { Bone age } \\
(\mathrm{yr})\end{array}$ & $\begin{array}{c}\text { Peak GH } \\
\text { pharmacologic } \\
(\mathrm{ng} / \mathrm{ml})\end{array}$ & GHRH test & $\begin{array}{c}\text { Growth velocity } \\
(\mathrm{cm} / \mathrm{yr})\end{array}$ & $\begin{array}{c}\text { Height } \\
(\mathrm{SDS} \text { at } \mathrm{CA})^{*}\end{array}$ & $\begin{array}{c}\text { Growth velocity } \\
\text { (SDS at CA)* }\end{array}$ & $\begin{array}{c}\text { Other hormonal } \\
\text { replacement } \dagger\end{array}$ \\
\hline \multicolumn{9}{|c|}{ University of Virginia } \\
\hline 2 & 4.3 & 2 & $1.6 \ddagger$ & 12.1 & 0.6 & -4.3 & -5.7 & \\
\hline 24 & 15.8 & 13.5 & $0.3 \S$ & 3.2 & 4.6 & -4.2 & +1.4 & \\
\hline \multicolumn{9}{|l|}{ Denver } \\
\hline 8 & 8 & 5 & 2.4 & 15.0 & 3.5 & -2.7 & -2.6 & $\mathrm{~T}_{4}$ \\
\hline \multicolumn{9}{|l|}{ Tufts } \\
\hline 23 & 11.2 & 9 & $2.1 \|$ & 12.5 & 3.9 & -3.2 & -1.6 & \\
\hline Mean & 9.8 & 7.4 & 1.3 & 10.7 & 3.2 & & & \\
\hline$\pm \mathrm{SD}$ & 4.9 & 5.0 & 0.9 & 5.2 & 1.8 & & & \\
\hline Range & $4.3-15.8$ & $2-13.5$ & $0.3-2.1$ & $3.2-15.2$ & $0.6-4.6$ & $-2.7--4.3$ & $+1.4--5.7$ & \\
\hline
\end{tabular}

* SD score at chronologic age derived from tables of Tanner et al. (6).

$\uparrow \mathrm{T}_{4}, \mathrm{~L}$-thyroxine.

\$ L-dopa/arginine.

$\S$ Insulin tolerance test.

\|I Insulin/clonidine.

I Note small number of patients. 